\title{
Management Effectiveness of Southeast Aru Islands Marine Conservation Area
}

\author{
Fernando Dayandri Willem Dangeubun ${ }^{1 *}$, Budy Wiryawan², Mustaruddin², Ari Purbayanto \\ ${ }^{1}$ Department of Living Aquatic Resources Management, Faculty of Fisheries and Marine Science, Pattimura University, \\ Jl. Ir. M. Putuhena, Campus Poka Ambon, Ambon 97116, Indonesia \\ ${ }^{2}$ Department of Fisheries Resources Utilization, Faculty of Fisheries and Marine Science, Academic Ring Road, Campus IPB \\ Dramaga, PO Box 168, Bogor 16680, Indonesia
}

Received September 18, 2012/Accepted June 25, 2013

\begin{abstract}
Southeast Aru Islands Marine Conservation Area (SE Aru MCA) has been existed for nearly 21 years, a period that long enough for a timely evaluation about how far improvement of management has been made in the area in question, i.e. whether management has improved situation of local communities and marine resources availability in the area. This study, therefore, aims at assessing management effectiveness and impacts of SE Aru MCA. Results suggest that the MCA, which was originally established as a marine nature reserve (Cagar Alam Laut, CAL) in 1991 and changed status into marine sanctuary in 2009, has not yet produced the expected positive impacts. Assessment using available tools indicated that the management level of SE Aru MCA is at level 1, with percentage of $34.12 \%$, meaning it is still at initiation stage and less effective in terms of management outcomes. Index of conservation area effectiveness with a value of 0.387 shows that the overall conservation area in the 3 categories mentioned above is less effective, therefore conservation effect has not been able to solve area problems. It is concluded that, after more than 20 years exists in the area, few benefits have been produced by SE Aru MCA for local people associated with it and biological resources in it.
\end{abstract}

Keywords: marine sanctuary, conservation, effectiveness, impact

*Correspondence author, email:fernando_dange@yahoo.com,telp: +62-813-8958-2633

\section{Introduction}

Effectiveness of marine conservation area management is an effort to measure degree of area management to examine whether it has achieved the objectives of a marine conservation area (Hockings et al. 2006). There are many aspects in every marine conservation area (MCA), such as biophysical factors, governance, and social economy, that directly or indirectly affect the total management performance. When designed properly and managed effectively, MCA will play important roles in protecting the ecosystem (IUCN-WCPA 2008). Therefore, many institutions and governmental agencies as well as public have a high expectation on MCA in maintaining the ecosystem functions and marine biodiversity, in addition to improving the socio-economic condition as a result of the increase in fishery production, so that income and food sovereignty will improve (Parks et al. 2006).

Southeast Aru Islands conservation area is one of the conservation areas established by the central government based on Decree of Ministry of Forestry Republic of Indonesia No. 27/Kpts-II/1991 holding the status of Marine Nature Reserve of Southeast Aru Islands, which was later handed over to the Ministry of Marine and Fisheries in 2009 through Decree of Ministry of Marine and Fisheries No 63/Men/2009 with the status changed into Aquatic Nature Sanctuary of Southeast Aru Islands.
History of Southeast Aru Conservation Area has been started 21 years ago. In summary, research studies underlying the establishment of marine reserves is now converted into marine nature Reserve (SAP) and it showed that the existence of ecosystem and its resources in Southeast Aru conservation area has been declining due to unsustainable exploitation (Far-Far 2005). This occured because there was lack of knowledge of local community about functions and benefits of the area (PUSDI-PSL UNPATTI 1993; Person \& de Jongh 1993; Hitipeuw et al. 1994); unclearly boundary of conservation area including zonation plan and unavailable plan of management area (Yayasan Hualopu 1997); the activities of community empowerment have not done in a good way (Maitimu 1995); controlling and law enforcement of unregulated has not been optimally in the area (Djohani \& Alwi 1996). All of the various research above indicated that there are many things to be arranged in this area. Therefore, one of the aims which need to be in depth study was to analyse and to determine the extent of management effectivity level and conservation impact in this area in order to be an inputs to the management body, government in arranging, determining and implementation policies, program and activities in the area.

\section{Methods}

Data is obtained through searching for data and 
information related to biophysical condition, social economy and culture and governance, through interviews, focus group discussion, and secondary data sources from the result of related institution reviews. Data obtained were focused on government institutions, management bodies, and communities and other users in the area.

The determination of effectiveness level and impact of conservation area management was conducted by method using approach according to Carter et al. (2011), which is completed with Excel software. To calculate rank of conservation effect, several questions in the score card have been weighed based one of the criteria, (adapted from Kapos et al. 2009) i.e. implementation activity (IA), output (O), result $(\mathrm{R})$, and conservation effect $(\mathrm{CE})$. To calculate the percentage for the determination of conservation effect $(\mathrm{CE})$ rank a simple Equation [1] below is used:

$C E=\frac{N}{D} \times 100 \%$

note:

$C E=$ conservation effect $(\%)$

$N=$ number of CE questions with the answer"Yes"

$D=$ number of total CE questions relevant/applicable in a MCA

The percentage produced is directly correlated with the rank of CE as follows:

Rank- 1 CE has not yet measured or observed, or observed at less than a quarter $(<25 \%)$ of known effects

Rank-2 CE is measured or observed at more than a quarter $(>25 \%)$ but less than half $(<50 \%)$ of known effects

Rank-3 CE is measured or observed at more than half $(>50 \%)$ but less than three quarter $(<74 \%)$ of known effects

Rank-4 CE is measured or observed at more than three quarter ( $>75 \%$ ) of known effects.

To give a justification to the effectiveness of assessment, further analysis was done using index of conservation area effectiveness (IEKK) approach which was determined based on categories of biophysics (B), social economy (SE), and governance $(\mathrm{G})$ using Equation [2] modified from Morenoa et al (2001), as follows:

IEKK $=\frac{1}{3} \sum_{i=1}^{n} \sum_{j=1}^{o} \sum_{k=1}^{p}\left(I E_{i j k}\right)$

note:

IEKK $=$ index of conservation area effectiveness

$3=$ number of categories of conservation area assessment

$\mathrm{i} \quad=$ biophysical category

$\mathrm{j}=$ socio-economy category

$\mathrm{k} \quad=$ governance category

$\mathrm{n}, \mathrm{o}, \mathrm{p}=$ assessment table $($ Table $\mathrm{A}=1$; Table $\mathrm{B}=2$; Table $\mathrm{C}$ $=3$, and Table $\mathrm{D}=4$ )

$\mathrm{IE}_{\mathrm{ijk}}=$ effectiveness index for biophysical (B), socio economy (SE), and governance $(\mathrm{G})$ categories

Then $\mathrm{IE}_{\mathrm{ijk}}$ is obtained from Equation [3] to Equation [6]

$$
\mathrm{IE}_{\mathrm{ijk}}=f\left(\mathrm{IE}_{\mathrm{B}}, \mathrm{IE}_{\mathrm{SE}}, \mathrm{IE}_{\mathrm{G}}\right)
$$

$$
\begin{aligned}
& \mathrm{IE}_{\mathrm{B}}=\left(\frac{\sum Y_{B}}{\sum Y_{B}+\sum T_{B}}\right) \times 100 \\
& \mathrm{IE}_{\mathrm{SE}}=\left(\frac{\sum Y_{B}}{\sum Y_{S E}+\sum T_{S E}}\right) \times 100 \\
& \mathrm{IE}_{\mathrm{G}}=\left(\frac{\sum Y_{B}}{\sum Y_{G}+\sum T_{G}}\right) \times 100
\end{aligned}
$$

note:

$\mathrm{Y}=$ Answer "Yes" for each question in each category

$\mathrm{T}=$ Answer "No" for each question in each category

Index value was determined in 5 class ranges, so that the measured effectiveness level can be categorized as not effective, less effective, fairly effective, and very effective $(1-5)$.

\section{Results and Discussion}

Effectiveness of conservation area management Regulation of Ministry of Maritime and Fisheries the Republic of Indonesia No. Per.02/Men/2009 concerning Procedure in Marine Conservation Area Establishment section 1 verse (1) defined marine conservation area as protected marine area, managed by using zonation system, to achieve a sustainable management of fishery resources and environment. Furthermore, in section 2 verse (1) it is stated that the implementation of marine conservation area establishment conducted with the following objectives:

1 to protect and sustain fish resources and important ecosystem types in marine area to ensure the sustainability of its ecological functions

2 to realize a sustainable use of fish resources and ecosystem as well as its environmental

3 to sustain local wisdom in the management of fish resources in and/or around marine conservation area, and

4 to improve people's welfare around marine conservation area.

While the goal of conservation area itself is stated in version (2) i.e. a sustainable use of fish resources and its ecosystem, and the environmental services within, while maintaining local wisdom, so as to ensure availability, sustainability, and the improvement of value quality and its diversity, to improve people's welfare, especially those living around the marine conservation area. Area zoning is a division of areas (zones) that reflects a certain treatment in each zone. Zoning aims at optimizing the function and allocation of natural resources and ecosystem potentials in each part of the area.

Marine conservation area zonation plan refers to Law No 45 year 2009 concerning fisheries and Government Regulation No. 60 Year 2007 concerning fish resources, consists of core zone, sustainable fisheries zone, utilization zone, and other zones. For specific cases, there will be subzones as part of the four major zones in which the determination will be adjusted based on potential, characteristics, a and social-economy of surrounding community consideration. Based on Regulation of Minister of Marine and Fisheries the Republic of Indonesia No 
Per.30/Men/2010 concerning Management Plan and Zonation of Marine Conservation Area section 14 stated that sustainable fisheries zone is allocated for protection of fish habitat and population, fish exploitation using environmentally friendly gears and methods, environmentally friendly cultivation, tourism and recreation, research and development, and education.

Southeast Aru Islands Conservation Area is one of conservation area established by central government through Decree of Minister of Forestry RI No 27/KptsII/1991 with a status of Marine Nature Reserve of Southeast Aru Islands. Southeast Aru Islands is established based on the results of biophysical and socio-economic survey which indicated that the existence of this area should be maintained because it holds endemic resource potentials, those are turtle, dugong and crocodile, and supported by a diversity of ecosystem. Other considerations used to decide this area as conservation area there are 7 islands, in which 3 of them are the outermost islands of Indonesia that are located at the boundary of Indonesia and Australia non-inhabitant very small island and is a historic area for people of Aru Islands.

Rank of area management Result of analysis on electronic work sheets showed that the conservation area still in the stage of first management level or that the management is just about to start. This conclusion is based on the result of analysis that the score value at level 1 has reached $78.57 \%$, while it is stipulated in the electronic works sheet that if the score is equal or greater that $75 \%$ the level has reached the expected positive results (Table 1).

The results of calculation showed that the management level 2 has reached $28.57 \%$, level 3 management has reached $7.14 \%$, while level 4 and 5 of management do not have $0 \%$. Therefore, based on the consensus of threshold score equal or greater than $75 \%$, it can be said that the management levels of $2,3,4$, and 5 have not reached the expected positive results (Figure 1).

Based on the obtained score values it is revealed that the management level 1 to 5 still have components that have not been implemented yet. Therefore, it becomes necessary to describe those components to make recommendation for the management body in preparing and implementing management efforts.

Management level 1 The result of analysis showed that management level 1 is considered has reached the expected result in area management. However, the achieved score value $(78.57 \%)$ showed that there is $21.43 \%$ of category (Cat) and conservation criteria (CC) that have not been achieved; therefore, it is necessary to know which category or conservation criteria that have not been implemented yet.

In the electronic score Table A, there are 14 questions that consist of biophysical category (B), social-economy category (SE), governance category $(\mathrm{G})$, and 4 conservation criteria (CC), those are implementation activity (IA), output $(\mathrm{O})$, result $(\mathrm{R})$, and conservation effect $(\mathrm{CE})$. Category and conservation criteria that have not yet been implemented can be seen in Table 2 .

Table 2 shows that level of biophysical, social economy and governance categories have not yet implemented one question, while based on conservation criteria there is 1 implementation activity and 2 output that have not yet been implemented by the management body in optimizing the area. Based on the definition of implementation activity, which is an activity to help actions related to conservation, there is 1 activity that has not been implemented yet to support other actions. While referring to the definition of output, it can be said that by not having held public consultation yet, various inputs, both from government and public, have not yet integrated into the various documentation in the planning of area management. Therefore, some recommendation stated before can be a reference for the management to implement them.

Management level 2 Results of analysis of level 2 management is relatively low, and it has not yet achieved the desired positive results. Based on the achievement of score value at management level $2(28.57 \%)$ it shows that there is still $71.43 \%$ of category (Cat) and conservation criteria (CC) that have not yet been conducted. Therefore, at this level it is

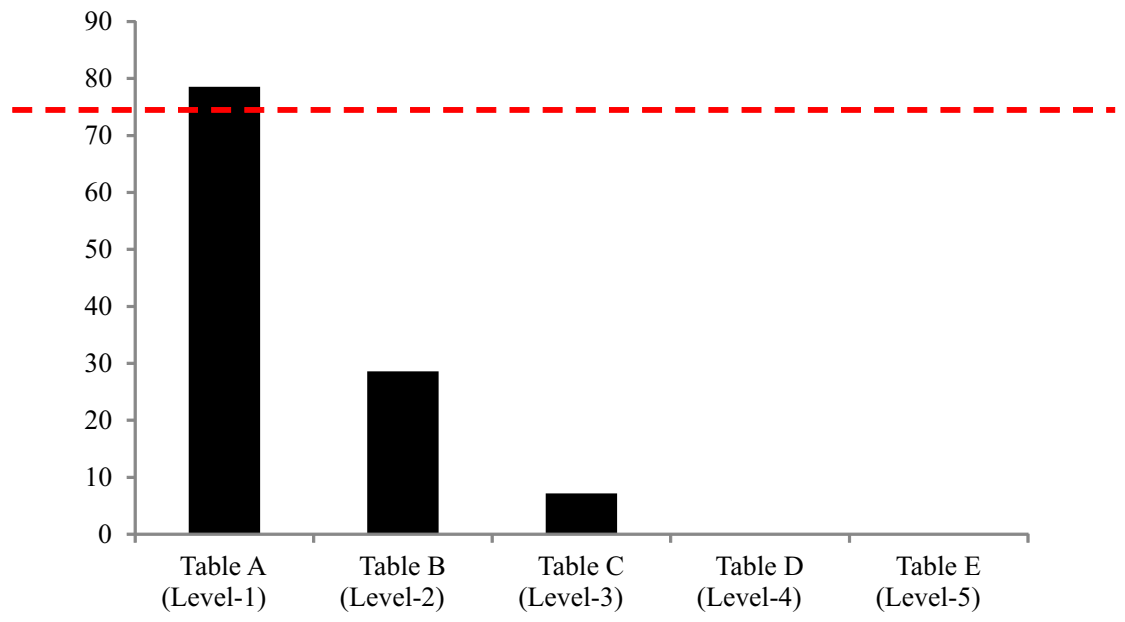

Figure 1 Levels of area management. 
Table 1 Results of calculation of management level

\begin{tabular}{lccccc}
\hline Results & $\begin{array}{l}\text { Total 'Yes' } \\
\text { Recorded }\end{array}$ & $\begin{array}{l}\text { Total 'No' } \\
\text { Recorded }\end{array}$ & $\begin{array}{l}\text { Total 'Do not } \\
\text { Know' } \\
\text { Recorded }\end{array}$ & $\begin{array}{l}\text { Total 'Not } \\
\text { Applicable' } \\
\text { Recorded }\end{array}$ & $\begin{array}{l}\text { Proportion of 'Yes' }= \\
\text { Total 'Yes' recorded / } \\
\text { Total expected score ( - } \\
\text { TA) × 100. (\%) }\end{array}$ \\
\hline Table A (Level 1) & 11 & 0 & 3 & 0 & 78.57 \\
Table B (Level 2) & 4 & 10 & 0 & 0 & 28.57 \\
Table C (Level 3) & 1 & 12 & 1 & 0 & 7.14 \\
Table D (Level 4) & 0 & 13 & 1 & 0 & 0.00 \\
Table E (Level 5) & 0 & 9 & 5 & 0 & 0.00 \\
\hline
\end{tabular}

Table 2 Unanswered management score card (Electronic score table A)

\begin{tabular}{|c|c|c|c|}
\hline Cat & $\mathrm{CC}$ & Question & Direction \\
\hline $\mathrm{G}$ & IA & $\begin{array}{l}\text { Has public consultation been } \\
\text { done? }\end{array}$ & $\begin{array}{l}1 \text { All management planning need public consultation at } \\
\text { government and community levels. } \\
2 \text { The prepared planning document should involve all users } \\
\text { of the area. }\end{array}$ \\
\hline B & $\mathrm{O}$ & $\begin{array}{l}\text { Are the results of } \\
\text { biophysical survey used to } \\
\text { determine SMART } \\
\text { objectives and goals? }\end{array}$ & $\begin{array}{l}1 \text { Preparation of management plan should be based on } \\
\text { baseline survey on biophysics and people's activities. } \\
2 \text { Management plan document should be informed to local } \\
\text { government as soon as possible to be included into } \\
\text { regional planning. }\end{array}$ \\
\hline $\mathrm{SE}$ & $\mathrm{O}$ & $\begin{array}{l}\text { Are the results of social } \\
\text { economy survey used to } \\
\text { determine "SMART" } \\
\text { objectives and goals for the } \\
\text { social-economy intervention } \\
\text { that will be achieved through } \\
\text { MCA? }\end{array}$ & $\begin{array}{l}1 \text { Economic empowerment and capacity building of } \\
\text { community are one of important objectives to be } \\
\text { determined in area management objectives. } \\
2 \text { Alternative livelihood is one of the best solutions, but it } \\
\text { needs to consider sustainability aspect. } \\
3 \text { Preparation of management plan that provides space for } \\
\text { utilization by community while paying att ention to social, } \\
\text { economy, and cultural aspects. }\end{array}$ \\
\hline
\end{tabular}

expected that the management body seriously put efforts to improve the score value to approach the benchmark (above $75 \%$ ) or directed it the maximum point $(100 \%)$.

In the table of electronic score B, there are 14 questions at similar category level and conservation criteria that have not yet been implemented (Table 3). Of the 14 questions in the electronic score model B sheet only 4 questions that have been implemented "Yes", while the other 10 has not been implemented yet "No or Do not know".

According to (Carter et al. 2011), an area at the management level 2 already has establishment status, management institution, zonation, and management plan. Furthermore, each level of management is detailed into general category, so that if the area has reached management level 2 it means it has already passed through management level 1 and fulfill all the criteria for level 2, those are (1) unit or management organization has owned appropriate management or capacity to implement area management, (2) management plan and zonation are already available, (3) supporting infrastructure is available, and (4) funding support is available.

Based on these statement, it can be said that the conservation area has only fulfilled 2 requirements, those are establishment status and management body, while other criteria, such as zonation plan and management plan, supporting facilities, and funding program for the management interest have not yet been implemented. That is the reason why at this level it only achieved $28.57 \%$; therefore the management body should as soon as possible put its effort to fulfill all the requirement to accelerate the area management efforts.

Management level 3 The management level 3 is the level of management with the lowest score in the electronic score card compared to other levels of management or in other words, the management level has implemented various activities revealed through the questions in the score cards. At this management level, the achieved score was $7.14 \%$, which means there is $92.96 \%$ of activities that have not yet been implemented, or in other words only 1 question out of 14 that was answered (Table 4).

Based on the scope of management levels and detailed criteria of an area that fulfill the criteria of management level 3 according to Carter et al. (2011), which are:

1 endorsement of management plan and zonation plan,

2 standard operational procedure is available,

3 implementation of management plan and zonation, and

4 establishment of marine conservation area, therefore at the management level 3 the conservation area has only fulfilled 1 criteria, that is the area establishment.

Management level 4 and 5 Based on the result of analysis of management effectiveness level, the conservation area is at management level 1, while at the management level 4 and 5 
the area has not had value $(0 \%)$. Based on the criteria by Carter et al. (2011) an area that have reached management level 4 should have passed the following criteria: boundary establishment, institutionalized, resource management, social economy and cultural management. An area will have reached the management level 5 when the area has fulfilled the following criteria: the management of MPA has improved people's welfare, and sustainable funding.

In general, the management effectiveness level of Southeast Aru Island conservation area can be described as follows:

1 the management of Southeast Aru Islands conservation area is at level 1 , which means that the area is in the initiation phase with an achievement value of $78.57 \%$, or based on the criteria of achievement level is fairly effective.

2 at the management level 2, or establishment phase, the conservation area have reached only $28.57 \%$ achievement value, which means less effective.
3 at the management level 3 , the minimum management phase, the conservation area has only reached $7.14 \%$ of achievement value, so that it falls into not effective category.

4 the management level 4 , the effective management phase, the achievement value was $0 \%$ or based on the criteria of achievement it was not effective.

5 conservation area management at level 5 means that the area has already in the self-sustaining/independent phase; in this case it has $0 \%$ of achievement value which based on the criteria of achievement level is not effective.

6 in a whole, based on the criteria of achievement level the management of conservation area has only reached $34.12 \%$, which means that the conservation area management is less effective.

Effectiveness index of biophysical category (IEB) Based on the number of questions on biophysical category from electronic Table A-D, i.e. 10 questions, 2 questions (20\%)

Table 3 Unanswered management score card (Electronic score table B)

\begin{tabular}{|c|c|c|c|}
\hline Cat & $\mathrm{CC}$ & Question & Direction \\
\hline $\mathrm{G}$ & IA & $\begin{array}{l}\text { Are local co mmunities } \\
\text { involved in the plann ing } \\
\text { process of MCA? }\end{array}$ & $\begin{array}{l}1 \text { Need to involve community and other users in the preparation } \\
\text { of management planning. }\end{array}$ \\
\hline G & IA & $\begin{array}{l}\text { Is local government } \\
\text { involved in the planning } \\
\text { process of MCA? }\end{array}$ & $\begin{array}{l}2 \text { Need to involve local government in the preparation of } \\
\text { management plan. This is necessary so that in addition to } \\
\text { giving input the area management plan into regional } \\
\text { development plan and program. }\end{array}$ \\
\hline $\mathrm{G}$ & IA & $\begin{array}{l}\text { Have regulation and } \\
\text { guidelines on MCA been } \\
\text { placed in strategic } \\
\text { locations so that local } \\
\text { community can see and } \\
\text { read them easily? }\end{array}$ & $\begin{array}{l}3 \text { Campaign and information disbursement on the area are needed } \\
4 \text { It is necessary to give data on area boundaries to every vessel in } \\
\text { Arafura waters so that they will not do the catching inside } \\
\text { conservation area. } \\
5 \text { Information on area boundaries should also be given to Navy, } \\
\text { PolAir, and Fisheries Guards. }\end{array}$ \\
\hline B & IA & $\begin{array}{l}\text { Has regular biophysical } \\
\text { monitoring been started? }\end{array}$ & $\begin{array}{l}6 \text { Biophysical monitoring should be done periodically, } \\
\text { considering the vulnerability of the areato destructive use of } \\
\text { resources. }\end{array}$ \\
\hline $\mathrm{SE}$ & IA & $\begin{array}{l}\text { Has regular social } \\
\text { monitoring been started? }\end{array}$ & $\begin{array}{l}7 \text { Periodic social monitoring should also be conducted to examine } \\
\text { changes in people's behavior to the existence of conservation } \\
\text { area. }\end{array}$ \\
\hline G & $\mathrm{O}$ & $\begin{array}{l}\text { Has MCA management } \\
\text { plan been accepted by the } \\
\text { community? }\end{array}$ & $\begin{array}{l}8 \text { The area management plan should be done as soon as possible } \\
\text { and be conveyed to the community so that they understand and } \\
\text { aware of the management plan that is being implemented . }\end{array}$ \\
\hline G & $\mathrm{O}$ & $\begin{array}{l}\text { Has MCA management } \\
\text { plan been accepted by } \\
\text { local government? }\end{array}$ & $\begin{array}{l}9 \text { The area management plan should be presented to the } \\
\text { government so that it soon be integrated into regional/local } \\
\text { development plan. }\end{array}$ \\
\hline G & $\mathrm{O}$ & $\begin{array}{l}\text { Does MCA have zonation } \\
\text { plan (either as part of } \\
\text { MCA planning document } \\
\text { or separate document)? }\end{array}$ & $\begin{array}{l}10 \text { Management plan should include zonation plan in separate } \\
\text { document. } \\
11 \text { Zonation plan is expected to accommodate community } \\
\text { traditional zonation. } \\
12 \text { Zoning system should accommodate the interest of traditional } \\
\text { harvesting site. }\end{array}$ \\
\hline $\mathrm{G}$ & $\mathrm{O}$ & $\begin{array}{l}\text { Have buoyant, signs and } \\
\text { boundaries been } \\
\text { established? }\end{array}$ & $\begin{array}{l}13 \text { It is necessary to make buoyant for area boundaries, } \\
\text { considering that the area is very large and fishing vessels } \\
\text { usually use trawl in the area }\end{array}$ \\
\hline G & $\mathrm{O}$ & $\begin{array}{l}\text { Have infrastructure been } \\
\text { built to support MCA } \\
\text { management? }\end{array}$ & $\begin{array}{l}14 \text { It is necessary to build field posts in the conservation area. In } \\
\text { addition to post or office it is also expected to have efforts in } \\
\text { turtle nursery in the area. }\end{array}$ \\
\hline
\end{tabular}

Cat: category; CC: conservation criteria; G: governance; IA: implementation activity; B: biophysical; O: output; SE: social economy 
Table 4 Unanswered score card (Electronic score table C)

\begin{tabular}{|c|c|c|c|}
\hline Cat & $\mathrm{CC}$ & Question & Direction \\
\hline $\mathrm{G}$ & IA & $\begin{array}{l}\text { Does management body } \\
\text { actively implement the } \\
\text { management plan? }\end{array}$ & $\begin{array}{l}1 \text { Management Plan document should not be treated as pre- } \\
\text { requisite document in which the planned activities are not } \\
\text { implemented. }\end{array}$ \\
\hline $\mathrm{G}$ & IA & $\begin{array}{l}\text { Has the opportunity for } \\
\text { sustainable funding been } \\
\text { considered? }\end{array}$ & $\begin{array}{l}2 \text { Management plan should be supported by a sustainable } \\
\text { funding plan. } \\
3 \text { It needs funding support from various institutions in local, } \\
\text { national and international levels. }\end{array}$ \\
\hline G & IA & $\begin{array}{l}\text { Is there a way for local } \\
\text { community to file their } \\
\text { complaints/problems to the } \\
\text { Management Body? }\end{array}$ & $\begin{array}{l}4 \text { It is necessary to set up a complaint post both on destructive } \\
\text { activities in the area and on groups or certain organization } \\
\text { that use the area for their own benefit. }\end{array}$ \\
\hline B & IA & $\begin{array}{l}\text { Have the results of biophysical } \\
\text { monitoring been analyzed to } \\
\text { reveal the trend of condition? }\end{array}$ & $\begin{array}{l}\text { Regular and continuous biophysical monitoring is very } \\
\text { important to be conducted to obtain trend of changes in area } \\
\text { environment. }\end{array}$ \\
\hline SE & IA & $\begin{array}{l}\text { Have the results of social } \\
\text { component monitoring been } \\
\text { analyzed to reveal the trend of } \\
\text { change? }\end{array}$ & $\begin{array}{l}\text { Regular and continuous social monitoring is very important } \\
\text { to be conducted to obtain trend in community change. }\end{array}$ \\
\hline G & $\mathrm{O}$ & $\begin{array}{l}\text { Has group to enforce regulation } \\
\text { of MCA been established? }\end{array}$ & $\begin{array}{l}7 \text { It is necessary to establish watch groups and regulation } \\
\text { enforcement group at District level and supervisory team at } \\
\text { the community level. }\end{array}$ \\
\hline G & $\mathrm{O}$ & $\begin{array}{l}\text { Are the enforcement activities } \\
\text { of MCA regulation being } \\
\text { implemented regularly? }\end{array}$ & $\begin{array}{l}\text { Regular rule enforcement is necessary to give deterrent effect } \\
\text { for the offender. }\end{array}$ \\
\hline G & $\mathrm{O}$ & $\begin{array}{l}\text { Is the court for MCA regulation } \\
\text { being done regularly? }\end{array}$ & $\begin{array}{l}9 \text { Collaboration between management body and law } \\
\text { enforcement should be maintained so that any offense will be } \\
\text { well. }\end{array}$ \\
\hline G & $\mathrm{O}$ & $\begin{array}{l}\text { Are all information signs, } \\
\text { boundary signs and buoyant } \\
\text { still in place? }\end{array}$ & $\begin{array}{l}10 \text { Setting up of warning signs, boundary signs and buoyant } \\
\text { should be prioritized to ensure boundaries. }\end{array}$ \\
\hline G & $\mathrm{R}$ & $\begin{array}{l}\text { Has the MCA zonation Plan } \\
\text { been accepted by local } \\
\text { community? }\end{array}$ & $\begin{array}{l}11 \text { Zonation Plan of the MCA of Southeast Aru Islands should } \\
\text { be made based on local wisdom and pay attention to } \\
\text { traditional use area. }\end{array}$ \\
\hline $\mathrm{G}$ & $\mathrm{R}$ & $\begin{array}{l}\text { Has the MCA management } \\
\text { plan been accepted by local } \\
\text { government? }\end{array}$ & $\begin{array}{l}12 \text { Zonation Plan of the MCA of Southeast Aru Islands should } \\
\text { be made by considering the District's Spatial Plan (RTRW). }\end{array}$ \\
\hline $\mathrm{G}$ & $\mathrm{R}$ & $\begin{array}{l}\text { Has the MCA management } \\
\text { plan been adopted by } \\
\text { community? }\end{array}$ & $\begin{array}{l}13 \text { Management plan of Southeast Aru Islands Conservation area } \\
\text { should be made based on local community wisdom. }\end{array}$ \\
\hline G & $\mathrm{R}$ & $\begin{array}{l}\text { Has the MCA management } \\
\text { plan been adopted by the } \\
\text { government? }\end{array}$ & $\begin{array}{l}14 \text { The management plan should be known by local government } \\
\text { so that the government can accommodate it in the long term } \\
\text { and medium term of development plan. }\end{array}$ \\
\hline
\end{tabular}

Cat: category; CC: conservation criteria; G: governance; IA: implementation activity; B: biophysical; O: output; SE: social economy

obtained "Yes" answer, 7 questions (70\%) obtained "No" answer or not implemented, and 1 question obtained "Do not Know" answer, resulting in the value of effectiveness index of conservation area (IEB) of 0.22 . Therefore, it can be said that at the biophysical category the effectiveness level is less effective, marked with yellow color.

Based on this index value, the conservation area management has not shown any significant progress for the improvement of resources and its environment, and even if it were paired with the utilization there has been decrease in the resources in the area. The result of this study is in line with several previous researches that show that coastal ecosystem in the world potentially interact with human activities, so there are no coastal areas and small islands that is still untouched by human (Jackson \& Sala 2001; Stachowitsch 2003; Halpern et al. 2008). The reason of the decrease in fisheries resources in the area is the increase in population density which in turn give impact on the increase in utilization activities both legal and illegal. Human influence is very big in coastal ecosystem (Vitousek et al. 1997; Halpern et al. 2008). Here, conflicting human activities pressure response on ecosystem (Crain et al. 2008; Darling \& Côté 2008; Doak et al. 2008; Halpern et al. 2008).

Index of effectiveness social-economy category (IESE) The total questions in social-economy category for all table are 11 questions, 5 of them have been implemented, with "Yes" answer, while 5 have not yet been implemented with "No" answer and 1 question was not known "Do not know". Therefore, the total percentage of the sum of implemented questions is similar to those of non-implemented questions, which is $45 \%$. If the "Do not know" is in fact not yet implemented, the non-implemented social economy would be $65.5 \%$ and vice versa.

Changes in fisheries resource (biophysical condition) coincide with efforts of community in the area to fulfill their 
needs, so that if the social economy condition is not taken care of, it will disturb the sustainability of area biophysical condition. At present, based on the result of analysis on fisheries community's characteristics, people feel pressures because of the more expensive living cost, limit access to child education, health, electricity, transportation and market access to sell their catch. As a consequence exploitation of resources becomes uncontrolled, and tend to be destructive. Therefore, it is important for the management body to design, establish and implement management plan according to local community's needs. This is in line with the main role of protection area, those are biodiversity conservation, together with sustainable resource management, should create benefit to the surrounding communities (Brodziak et al. 2005; Douvere 2008; Worm et al. 2009). In developing countries the isolation of communities in the protection areas often trigger them to struggle or fight in many ways to obtain resources for their daily needs so that it influence resource conservation (Straede \& Treue 2006).

Conservation and poverty alleviation need to be handled together through collaboration between community and government in order to achieve conservation objectives (Adams et al. 2004). Community based conservation has become a paradigm for conservation organizations for the last 20 years (Browder 2002; Gjertsen 2005). To ensure that protected areas achieve local collaboration and sustain in the future, a deep understanding on socio-economic dynamics will be very much influence current and future resource utilization inside and outside protected areas (de Fries et al. 2007).

Effectiveness index on the governance category (IEG) The highest number of questions are those related to governance (35 questions). Out of 35 questions, 14\% have been implemented, $51.4 \%$ have not yet been implemented, while 8.6\% were unknown (whether they have been implemented or not), because the answer were "Do not know". Therefore, the effectiveness index on governance was 0.44 or the implementation of governance was effective. Similar to the social economy category, if the 3 "Do not know" questions have not yet been implemented, this will lower the effectiveness status of area management to the category of less effective and vice versa.

By looking at the level of management effectiveness at the category of governance the answer to the policy implementation becomes clearer/stronger that the area was established on paper only to fulfill the requirement of amount of conservation areas, but the situation is worse than expected. Direction of development policy that only places economic system and function as priorities and while ignoring ecological, social and cultural function will create complicated problems and long term social conflict. Therefore, government try to build and develop balance in ecological, economic, social and cultural function that are implemented in various policy tools and program (Gaines et al. 2010). In the meantime, policy that refers to development framework provides guidelines for the implementation of development objectives into program and activities (Germano et al. 2007).
Effectiveness index of conservation area Based on effectiveness index on biophysics (IEB), effectiveness index on social economy (IESE), and effectiveness index on governance (IEG), the effectiveness index of conservation area (IEKK) for the conservation area was 0.387 , meaning that the overall conservation area management in the 3 categories above is less effective, marked with yellow color. This shows that conservation area is not well managed as it should be according to law.

Conservation effect Based on the result of analysis it is shown that the conservation area is still in the management level 1 , which is an indication that this conservation area has just started. Range of activities in a newly started area usually are implementation, while the conservation effect will occur when the implementation activities have achieved goals and output that give positive impact for the environment as well as the community.

Pomeroy et al. (2004), stated that the objective of evaluation of management effectiveness is a management effort to achieve the objective and goals of protected area. The evaluation allows the improvement of protection management through learning, adaptation, and diagnose of specific problems that influence both the achieved objective(s) and goal(s). It is very important to conduct this evaluation to examine the effectiveness level, improve design, and provide information on the progress to the stakeholders. Monitoring is based on the periodic evaluation of specific ecosystem attributes, and current social economic condition or relevant to the DPL (Hockings et al. 2000). The objectives of this evaluation is to do a deep analysis on the result and output of the program and determine the level of success of achievement in program objectives; the result of the evaluation is used for the are management (Adrianto \& Matsuda 2004).

Strategic programs to encourage a conservation area management that is sustainable, effective and give impact on people's welfare should be done continuously through various efforts in conservation area management; such as: protection of habitat and marine biota population, rehabilitation of habitat and marine biota population, research and development, utilization of fish resources and environmental services, development of community social economy, supervision and control, monitoring and evaluation and developing collaboration and conservation network. The initiation program in the acceleration of marine conservation area to support sustainable fisheries include strengthening management plan, institutional, development of infrastructure in the area and development of area management system and sustainable funding commitment should be continuously conducted to support effective conservation area management.

\section{Conclusion}

The status of conservation area management of Southeast Aru Island is at level 1 (conservation area management has just started), where biophysics, social economy, and governance categories shows that program implementation and activities in the three categories is less 
effective. Index of conservation area effectiveness (IEKK) with a value of 0.387 , shows that the overall conservation area in the 3 categories mentioned above is less effective, therefore conservation effect has not been able to solve area problems.

\section{References}

Adams WM et al. 2004. Biodiversity conservation and the eradication of poverty. Science 306 (5699): 1146-1149. http://dx.doi.org/10.1126/science.1097920.

Adrianto L, Matsuda Y. 2004. Study on assessing economic vulnerability of small island regions. Journal Environment, Development and Sustainability 6(3): $\begin{array}{lllllll}3 & 1 & 7 & - & 3 & 3 & 6\end{array}$. http://dx.doi.org/10.1023/B:ENVI.0000029902.39214. d0.

Brodziak J, Traver M, Col L. 2005. Stock assessment of Georges Bank haddock, 1931-2004. Northeast Fisheries Science Center Ref. Doc. 06-11; 114 p.

Browder JO. 2002. Conservation and development projects in the Brazilian Amazon: Lessons from the community initiative program in Rondônia. Journal of Environmental Management 29(6): 750-762. http://dx.doi.org/10.1007/s00267-001-2613-3.

Carter E, Soemodinoto A, White A. 2011. Panduan Untuk Meningkatkan Efektivitas Pengelolaan Kawasan Konservasi Laut di Indonesia. Bali: The Nature Conservacy-Indonesia Marine Program.

Crain CM, Kroeker K, Halpern BS. 2008. Interactive and cumulative effects of multiple human stressors in marine systems. Journal Ecology 11:1304-1315.

Darling ES, Côté IM. 2008. Quantifying the evidence for ecological synergism. Journal Ecology 11: 1278-1286.

Djohani RH, Alwi T. 1996. An evaluation of conservation and development opportunities for the Aru Island. Fact finding mission Aru Tenggara Marine Reserve. Maluku Conservation and Natural Resources Project (MACONAR).

Doak DF et al. 2008. Understanding and predicting ecological dynamics: are major surprises inevitable. Journal Ecology 89:952-961. http://dx.doi.org/10.1890/07-0965.1.

Douvere F. 2008. The importance of marine spatial planning in advancing ecosystem-based sea use management. Journal Marine Policy 32: 762-771. http://dx.doi.org/10.1016/j.marpol.2008.03.021.

Far-Far R. 2005. Analisis kebijakan tentang kepatuhan nelayan terhadap kawasan konservasi pulau Enu, Kepulauan Aru, Maluku [Thesis]. Ambon: Program Pascasarjana Universitas Pattimur, Program Studi Ilmu Kelautan.
Fries R de, Hansen A, Turner BL, Reid R, Liu J. 2007. Land use change around protected areas: management to balance human needs and ecological function. Journal Ecology 17: 1031-1038.

Gaines SD, White C, Carr MH, Palumbi SR. 2010. Designing marine reserve networks for both conservation and fisheries management. In: Proceedings of the National Academy of Sciences, USA. $\begin{array}{llllllllllllllll}1 & 0 & 7 & : & 1 & 8 & 2 & 8 & 6 & - & 2 & 1 & 8 & 2 & 9\end{array}$. http://dx.doi.org/10.1073/pnas.0906473107.

Germano BP, Cesar SA, Ricci G. 2007. Enhancing Management Effectiveness of Marine Protected Areas. A Guidebook for Monitoring and Evaluation. Visca, Baybay, Leyte, Philippines: Leyte State University, Institute of Tropical Ecology, Marine Laboratory.

Gjertsen H. 2005. Can habitat protection lead to improvements in human well-being? Evidence from marine protected areas in the Philippines. Journal World De velopment 33(2): 199-217. http://dx.doi.org/10.1016/j.worlddev.2004.07.009.

Halpern BS, McLeod KL, Rosenberg AA, Crowder LB. 2008. Managing for cumulative impacts in ecosystem-based management through ocean zoning. Journal Ocean and Coastal Management 51:203-211. http://dx.doi.org/10.1016/j.ocecoaman.2007.08.002.

Hitipeuw C et al. 1994. Awareness and Education Programme for a Community Based Management of the Marine Resources in South-East Aru Strict Nature Reserve. Collaboration between PUSDI-PSL UNPATTI and EPM and PHPA/WWF.

Hockings M, Stolton S, Dudley N. 2000. Evaluating Effectiveness: A Framework for Assessing the Management of Protected Areas. Gland, Switzerland \& Cambridge, UK: IUCN (The World Conservation Union), $\mathrm{x}+121 \mathrm{p}$.

Hockings M, Stolton S, Leverington F, Dudley N, Courrau J. 2006. Evaluating Effectiveness: A Framework for Assessing Management Effectiveness of Protected Areas. Second edition. Gland, Switzerland \& Cambridge, UK: IUCN (The World Conservation Union).

[IUCN-WCPA] IUCN World Commission on Protected Areas. 2008. Establishing Resilient Marine Protected Area Networks-Making It Happen. Washington, DC: IUCN-WCPA, National Oceanic and Atmospheric Administration, and The Nature Conservation.

Jackson JBC, Sala E. 2001. Unnatural oceans. University of California, La Jolla, United States Journal Scientia Marina 65(2): 273-281.

Kapos V et al. 2009. Outcomes, not implementation, predict conservation success. Journal Oryx 43(3): 336-342. 
Maitimu B. 1995. Studi Eksploratif Aspek Sosial Ekonomi Masyarakat Pesisir Aru Tenggara di Sekitar Kawasan Cagar Alam Laut, Kecamatan Pulau-pulau Aru Kabupaten DATI II Maluku Tenggara. Ambon: PUSDIPSLUNPATTI.

Morenoa D, Aguilerab PA, Castro H. 2001. Assessment of the conservation status of seagrass (Posidonia oceanica) meadows: implications for monitoring strategy and the decision-making process. Journal Biological Conservation 102 : $325-332$. http://dx.doi.org/10.1016/S0006-3207(01)00080-5.

Parks JE, Pomeroy RS. Philibotte J. 2006. Experiences and Lessons Learned from Evaluating the Management Effectiveness of Marine Protected Areas in Southeast Asia and the Pacific Islands. Invited Paper Presentation from the CBD/IUCN International Workshop for Better Management of Protected Areas, Jeju Island, Korea, October 24-27.

Person, Jongh HH de. 1993. Seagrass distribution and seasonal biomass changes in relation to dugong grazing in the Moluccas, East Indonesia. Aquatic Botany 50: 120.

Pomeroy RS, Parks JE, Watson LM. 2004. How is Your MPA Doing? A Guidebook of Natural and Social Indicators for Evaluating Marine Protected Area Management Effectiveness. Gland, Switzerland \& Cambridge, UK: IUCN (The World Conservation Union).
PUSDI-PSL UNPATTI. 1993. Hewan Penyu dan Kima serta Tinjauan Aspek Botani, Sosial Ekonomi dan Budaya di Kepulauan Aru Bagian Tenggara. Laporan Survei. PUSDI-PSL UNPATTI bekerjasama dengan AIDENVIRONMENT Amsterdam.

Stachowitsch M. 2003. Research on intact marine ecosystems: a lost era. Marine Pollution Bulletin 46: 801-805. http://dx.doi.org/10.1016/S0025326X(03)00109-7.

Straede S, Treue T. 2006. Beyond buffer zone protection: a comparative study of park and buffer zone product's importance to villagers living inside Royal Chitwan National Park and to villagers living in its buffer zone. Journal of Environmental Management 78: 251-267. http://dx.doi.org/10.1016/j.jenvman.2005.03.017.

Vitousek PM, Mooney HA, Lubchenco J, Melillo JM. 1997. Human domination of Earth's ecosystems. Journal Science 277:494-499. http://dx.doi.org/10.1126/science.277.5325.494

Worm B et al. 2009. Rebuilding Global Fisheries. Journal Science 325 (5940): 578-585. http://dx.doi.org/10.1126/science. 1173146.

Yayasan Hualopu. 1997. Rencana Pengelolaan Sumberdaya Alam Kerakyatan di sekitar Kawasan Cagar Alam Laut Aru Tenggara, Dobo, Maluku Tenggara. Ambon: Yayasan Hualopu. 